Ігор Юдкін-Ріпун

доктор мистецтвознавства член-кореспондент НАМ України провідний науковий співробітник

Інститут мистецтвознавства, фольклористики та етнології iм. М. Т. Рильського НАН України

\section{Ihor Yudkin-Ripun}

Doctor of Art studies corresponding member of the National Academy of Arts of Ukraine leading researcher Rylski Institute for Art Studies, Folklore Studies and Ethnology of the NAS of Ukraine

dr.iyudkin@gmail.comｏrcid.org/0000-0002-4616-302X

\title{
«ЗВОРОТНИЙ ПЕРЕКЛАД» ЯК ФЕНОМЕНОЛОГІЧНА КОНЦЕПЦІЯ РОЗВИТКУ КУЛЬТУРИ
}

\author{
"ReVERsed Translation" \\ AS THE PHENOMENOLOGICAL CONCEPT \\ OF CULTURAL DEVELOPMENT
}

\begin{abstract}
Анотація. Широке тлумачення категорії рефлексії у феноменології уможливлює вживання її для висвітлення історичного буття традицій. Зокрема, на основі рефлексії складаються зворотні зв’язки (рекурсія) між різними історичними фазами розвитку традиції, визначаючи його замкнені цикли. Спеціальну форму таких зв'язків становить феномен зворотного перекладу, в якому уявний оригінал постає як зовнішній збудник внутрішніх перетворень традиції. Модель зворотного перекладу дозволяє висвітлювати такі питання українського культурогенезу, як перманентність барокової традиції, своєрідність бідермаєру та неокласицизму. Ключові слова: рефлексія, рекурсія, циклізація, інтерпретація, метафора бумерангу, ейдетика.
\end{abstract}

Вшановуючи славне 80-річччя О. К. Федорука, варто згадати, що вікопомним здобутком його творчої діяльності стало проведення рівно 30 років тому в м. Олесько міжнародної конференції, присвяченої українській бароковій культурі. Саме матеріали цієї конференції, оприлюднені через рік, започаткували те розгортання комплексного і системного дослідження феномена українського бароко, яким ознаменовані наступні десятиліття. Здобутки на цій ниві розширювали водночас і дослідницьке коло: насамперед постає проблема перманентності барокового спадку в українській культурі, його життєвості, творчої продуктивності в подальшому часі; таким же проблемним виявилося походження барокових феноменів, зокрема, явище фольклорно-барокової конвергенції, коли неможливо встановити, що первинне і що вторинне, що ішло від питомих народних традицій, а що від т. зв. "місіонерського» бароко; нарешті, впізнавання в барокових образах того змісту, який виходить далеко за межі доби, але осмислюється ії виразовими засобами.

Для дослідження таких питань корисними видаються методи феноменології та історичної поетики, спільність яких, що становить передумову їхньої ефективності, вже відзначалася, коли в останній третині XX століття помітним став т. зв. «діахронний поворот» в структуралізмі [7, с. 154], тобто зосеред- ження на історичній зумовленості досліджуваних явищ, на їхній ролі в культурогенезі. Тут слід звернути увагу на те, що розроблена в XX столітті гусерлівська редакція гегелівської феноменології демонструє цілу низку парадоксальних результатів. Насамперед, спрямована проти психологізму, вона здобула реальне застосування і продуктивний розвиток саме в психології, навіть у психотехніці. Так, центральне для цієї доктрини поняття рефлексії зробило блискучу кар'єру спочатку в гештальтпсихології (у вченні про продуктивне мислення М. Вертгеймера), а згодом на терені дослідження конфліктів, у розвитку т. зв. рефлексивного мислення (пов'язаного з іменами В. А. Лефевра, Г. П. Щедровицького, А. В. Брушлинського), коли кожен з супротивників віддзеркалює у своїй уяві хід думок суперника.

Та, мабуть, найбільш парадоксальним результатом стало також застосування феноменологічних категорій в історичній науці, зокрема, своєрідна версія розв'язування гегелівської проблеми логічного та історичного. Тут, як і в морфології культури О. Шпенглера, фактично було закладено підвалини віртуального моделювання історичних подій. Розумового експерименту для дослідження історичних можливостей. Відомо, що метафора «історія книга", «історія - театр» виявила цілком прагматичну, а не метафоричну ефективність, 
коли, приміром, було передбачено розшифрування крито-мікенських написів (так само, як і хетської мови) [1, с. 187]. Так само, як О. Шпенглер, розвиваючи принципи морфології Й. Гете, виявив продуктивність перенесення їх 3 царини живого світу на дослідження культури, перспективи феноменології відкрилися в застосуванні її понять до історії та в новому підході до старої гегелівської проблеми відношення логічного та історичного. На це звернув увагу Г. Шпет, київський учень Е. Гуссерля, вказавши, що «в проблемі інтерпретації знаходиться вузол, який щільно пов'язує історичну науку з логічним вченням» [10, с. 318].

Отже, за феноменологічного підходу важливою рушійною силою розвитку культури стає інтерпретація як форма рефлексії, в тому числі перекладацька практика в широкому сенсі, як переосмислення культурних традицій, своїх та сторонніх. Традиція постає як генеративний механізм породження текстів, що в історичному житті зазнає дивовижних метаморфоз. Зрозуміло, що історія, осмислена через інтерпретацію, постає як масштабний текст. Зі свого боку, від такого уподібнення історії та тексту, як написання «книги буття», один крок і до висновку про феномени «вічного повернення", до культу воскресіння, що єднав Миколу Гоголя i послідовників Адама Міцкевича, як з'ясував П. В. Михед [5, с. 172]. Культурогенез тоді прибирає вигляду масштабних історичних циклів, замкнених рефлексією, і саме тут відкривається перспектива відкриття іманентних властивостей історичного життя традиції. Для цього слід відзначити особливість замикання таких циклів на основі рефлексії.

1887 року французький математик Каміл Жордан довів теорему, яка фіксує начебто очевидність: будь-яка замкнена крива на площині ділить ї̈ на дві частини, внутрішню і зовнішню. Але для доведення цієї очевидності йому довелося розробити складний категоріальний апарат, що став згодом підмурівком нової математичної галузі - топології. Рефлексія, взята в широкому розумінні як замикання руху думки, як витворення циклу, може поширитися і на історичне життя традиції з цілою низкою далекосяжних наслідків. Відтак йдеться про утворення циклів, замкнених просторів, де діють автономні закономірності, що й відповідає вимогам перенесення феноменологічної методики на терен історії. Замкненість рефлексії виявляється придатною пояснювати циклізацію історичного процесу, а не лише текстової будови.

Такі цикли стають наочними, коли простежується дієвість традиції. Переживання далекої минувшини оживають в культурогенезі, коли вони, здається, давно забуті й утратили продуктивність. Історія демонструє петлі часу, коли традиція, виявляється, не відмерла, а лише на певний час відступила, існувала в прихованому вигляді як течія підземної річки. Ці феномени життєздатності традиції добре відомі в історії стилів.
У масштабі історичного часу розрізняють такі види рефлексії, як ретроспекції та рецидиви (пережитки), релікти та рудименти, ремінісценції та реставрації. Так, ретроспективне спрямування вочевидь засвідчують стилізації мови персонажів у дусі епохи Просвітництва в історичних драмах I. Кочерги «Фея гіркого мигдалю» та "Алмазне жорно». Пережиткові явища прикрашального ставлення до фольклору висміюється в «Співочих товариствах» В. Винниченка. Прадавнім реліктом, що здобуває нове життя і виявляє творчу продуктивність, стає вертепна драма в «Іродовій мороці» П. Куліша. Блискучий приклад рудиментів демонструє Іван Франко, чия повість «Перехресні стежки» містить в зародку характерні риси майбутнього експресіонізму 3 його страхіттями. Леся Українка В «Касандрі» інтуїтивно знайшла той ефект спостерігача, який впливає на спостережений предмет, що став надбанням природничої думки лише в середині XX століття. Релікт може ставати рудиментом і навпаки. Релікти фольклорної архаїки стали рудиментами розвитку стилістики неосинкретизму в культурі XX століття, натомість експериментальні шукання футуризму початку XX віку стали курйозними реліктами епохи.

Та має місце ще один вияв рефлексії в історичному часі, який визначається залежністю кожного наступного кроку від попереднього, т. зв. рекурентною залежністю історичних подій або рекурсією. Для його позначення відомий германіст О. В. Михайлов запропонував німецьке поняття Nachleben - дослівно «життя після життя", позначаючи ним «триваючу традицію бароко, що окремими своїми сторонами виходить за межі відведеного йому часу» [4, с. 390]. Широке розуміння замкненості рефлексії, ï̈ поширення на масштаби історичного життя традиції унаочнюється новим тлумаченням відомої метафори Ізіди, що здіймає покрив з історичної таїни з плином часу, з розгортанням історичних подій. Тут ця метафора обертається вже іншою, вже питомо українською, тим образом, який влучно визначений М. Коцюбинським - «Тіні забутих предків». Традиція, що починає своє «життя після життя», існує в прихованій, латентній формі, невидимо зберігаючи свою дієвість і виринаючи тоді, коли здається втраченою.

Для таких феноменів корисним видається запозичене 3 перекладацької практики поняття «зворотного перекладу», яке було запропоновано вживати в розширеному сенсі для дослідження проблем історичної поетики щойно згаданим О. В. Михайловим: «Провідний метод історії культури як науки - це зворотний переклад настільки, наскільки вся історія полягає в тому, що різні культурні явища ненастанно переводяться в інші, чужі їм культурні мови, часто з граничним переосмисленням змісту» [4, с. 16]. «Зворотний переклад» відтак постає в найширшому розумінні як евристичне знаряддя дослідження історич- 
ного буття текстів культури, їх перетворень та витлумачення. «Оригінал» постає тоді як своєрідне люстро, в якому віддзеркалюються власні творчі процеси, питомі традиції національної культури.

Чому ж начебто суто технічний перекладацький термін здобуває таке широке тлумачення? Така увага до зворотного перекладу зумовлена тим, що він не раз відігравав уже продуктивну роль в розвитку культури. Важливим історичним прецедентом було, зокрема, повернення до Європи спадщини Арістотеля, яке спочатку здійснювалося через арабські, а далі зроблені з них латинські переклади, повертаючись у двічі перетвореному вигляді. Так народився, зокрема, відомий ідейний рух аверроїзму (від імені Аверроеса, арабського перекладача і коментатора Арістотеля). Як відомо, лише 1259 року папа Урбан IV «доручив Вільтямові з Мербока перекласти твори Аристотеля 3 грецької, а Томі Аквінському і Альберту Великому - здійснити критичну інтерпретацію» [3, с. 7]. От чому саме Аквінат та засноване ним вчення томізму стали альтернативою аверроїзму, адже «саме в його час з'явилися якісні переклади Аристотеля безпосередньо з грецької мови, а не передані через арабську» [3, с. 12]. Цей прецедент обгрунтовує можливість застосування моделі зворотного перекладу і для аналізу деяких феноменів української культури.

Біля витоків нового українського красного письменства стоїть тридцятирічна праця Івана Котляревського над вітчизняною версією Енеїди. Зазвичай її ставлять до ряду незліченних перекладів-переспівів римського героїчного епосу. Але можна погодитися з Валерієм Шевчуком, який побачив у «Енеїді» криптографічний текст з глибоко прихованим потаємним змістом, де форма перекладу маскувала зашифровану інформацію про українську історію. Так, очевидна алегорія відродження Запорізької Січі на Кубані на чолі з Головатим [9, с. 13], вміщено відверті перекази уривків з козацьких літописів [9, с. 17]. Латинський оригінал дає тут лише привід для розвитку власних, питомих традицій, що випромінюються вітчизняною минувшиною і віддзеркалюються в пам'ятці римського епосу. Поряд 3 «Енеїдою» доречно зіставити ще один твір, відомий лише через польський переклад із загубленого французького оригіналу: йдеться про «Рукопис, знайдений у Сарагосі» Яна Потоцького, створений в ті ж роки. Тут так само виявився неістотним оригінал перекладу, що став допоміжним знаряддям для історичних траєкторій незалежної від нього образної системи твору, яка, наче промінь, народилася в задумі автора, віддзеркалилася від втраченого французького тексту і пішла власним шляхом.

Ідея упізнавання в чужому предметі, зокрема в предметі перекладу свого власного, перетвореного і відчуженого змісту, значно глибше вкорінена і ширше розповсюджена, ніж звичайно це уявляють. Коли в «Енеїді» по- зірно відтворюється латинський прообраз, то «Омирова Ільйонянка» Степана Руданського відверто розвиває традиції козацького літописання, де «Іліада» становить лише підпору тексту, побудованого хоча й як переклад, та зануреного в українські реалії. Як зазначав академік А. О. Білецький, «Руданський безжально обійшовся з гомерівськими власними іменами і назвами в своєму бажанні якнайбільше українізувати їх ..., така українізація часто межує 3 неможливістю ототожнення» [2, с. 407-408], так що перед читачем постає «Гомер, переодягнений бандуристом або кобзарем» [2, с. 413].

Наочні приклади петлі часу демонструє стиль бідермаєр, дослідження якого розгорталися паралельно з бароковою культурою. Значущість його для України пов'язана ще й 3 формуванням прози та прозаїчної культури в цілому в творчості Г. Квітки-Основ'яненка. Дискусійність цієї проблеми відзначив Дм. Чижевський у останньому курсі лекцій, зазначивши, що в Німеччині, звідки пішов цей термін, він позначав «протверезіння після захоплення романтичними ідеями», «обміщанення романтиків» [8, с. 489]. Ці слова писалися в середині XX століття, але подальше вивчення цього феномену довело обмеженість таких уявлень: зрештою, йшлося не про міщанство і тверезість, а, про повернення до тих живучих барокових традицій, які завжди підтримувалися народною релігійністю і відступали до затінку європейської свідомості лише в поверхневих, не закорінених в народі носіях книжкової "ученості». Цей напрямок коріниться і в такому загальноєвропейському русі, як «стерніанство», наслідування й розвиток манери англійського письменника Л. Стерна. Але особливо істотним видається те, що як у Hiмеччині, так в Україні він виявляв тяглість барокової традиції. Тут вже «зворотний переклад» постає як витлумачення півзабутої традиції, переклад їі на мову нових історичних реалій, тобто повернення сучасникам. Ці реалії постають як сторонній оригінал для перекладу, а власні традиції перетлумачують їх в процесі цілком самостійного розвитку.

Для П. Куліша уявним оригіналом для зворотного перекладу стали шекспірівські хроніки, генетичний зв'язок з якими його «Драмованої трилогії» $є$ відомим. Та перекладний взірець тут - лише привід для власної історичної міфотворчості, етіологічної та есхатологічної разом. Тут хроніки стали лише зовнішнім збудником творчого процесу, що пішов своїм власним шляхом.

Феномен українського неокласицизму, славетне "гроно п'ятірне нездоланних співців" (М. Драй-Хмара) продовжує також і програму Кирило-Мефодіївського братства, де нагадувалося про стару істину, що мова існує не лише для поширення думки, але і для ï приховування. Ця програма криптографії дістала нового життя в зверненні до тих предметів перекладів, на межі з містифікацією, де за вигаданим оригіналом перекладу стояли справді 
не позичені, а питомі джерела. Тут дивовижна стійкість традицій в Україні виявляється в їх здатності до невпинних метаморфоз, в їх мінливості, що змушує згадати образ античного Протея. У класичної тріади «мимесис - фантазія - мімікрія» (та, окрема, діегезис як особлива, суб'єктно обарвлена форма мимесису) всі ланки забезпечили незвичайну здатність до різноголосся, до динамічних перетворень голосів, до майстерного використання прихованих або явних стилістичних цитат, засвідченого безперечним лідером «грона» - Максимом Рильським [11, с. 88-93]. Що поетичний напрям, який, усвідомлюючи себе як ретроспекція, справді зростав на основі досвіду перекладацької практики та рефлексії над цим досвідом, став додатковим до ролі рефлексії, яка забезпечує тяглість традицій.

Іван Франко звичайно розглядається в одному ряді з сучасними йому натуралістами, і для цього $є$ підстави. Монументальний реалізм Е. Золя з його поетизацією повсякдення повсюдно присутній в його творах. Але очевидно також, що його творчість має й інші джерела, не менш значущі. Відбувається трансляція досвіду середньовічної агіографічної літератури, дидактичної поезії, який віддзеркалюється реаліями сучасності як оригіналом в ситуації із зворотним перекладом.

Виходячи за межі українського культури, можна вказати на ще один цікавий казус перекладацької практики - рецепцію Достоєвського в західному світі. Саме в Німеччині доби експресіонізму його творчість здобула широкий спектр інтерпретацій. То ж чи не було це тлумачення Достоєвського (приміром, у «Докторі Фаустусі» Т. Манна) саме упізнаванням власної минувшини, анамнези сом, де оригінал перекладу ставав лише збудником спогадів?
Нарешті, слід зазначити, що модель зворотного перекладу виявляється корисною для висвітлення міжвидових взаємин в культурі. В перспективі відкриттів останньої третини $\mathrm{XX}$ століття про відособлення вербального та візуального мислення та їх спеціалізацію в різних півкулях мозку (т. зв. подвійне кодування) концепція зворотного перекладу виявляється пов'язаною зі споконвічною гораціанською проблемою: зробити слово наочним, яскравим, домогтися ідеалу «поезія - як малярство». Свідчення подібного перетлумачення візуальних образів як оповідання про реальні події нагромаджено чимало: приміром, режисер С. Образцов ідентифікував центральний персонаж 3 картини М. Клодта «Остання весна» як свою двоюрідну сестру, померлу від сухот [6, с. 85]. Відтак «зворотний переклад» можна вважати законом ейдетичного мислення, коли ілюстрації до оповіді, переклади оповіді мовою візуального мистецтва стають джерелом для нової оповіді.

Таким чином, зворотний переклад визначає модель культурогенезу, яка виходить далеко за межі суто перекладацької техніки, реалізуючи феноменологічний принцип єдності історичного і логічного. Можна казати про своєрідний ефект бумеранга в житті художньої традиції, що збігається з платонівським анамнезом, пригадуванням у найширшому сенсі. Проміння, пущене в минувшину істориком, повертається бумерангом, оновлюючи свій сенс тим, від чого воно було відбите. Історичний процес демонструє своєрідні петлі часу, коли традиція відходить в сутінки, стаючи «тінями забутих предків», для того щоб знову опромінювати світ з гребінців нової хвилі свого історичного буття.

\section{Література}

1. Аверинцев С. С. «Морфология культуры» Освальда Шпенглера // Новые идеи в философии. 1991. М.: Наука, 1991. С. 183-203.

2. Білецький А. О. «Ільйонянка» - перший повний український переклад Гомерової «Іліади» / Руданський С. Твори в 3 т. Т. 3. Київ: Наукова думка, 1973. С. 405-418.

3. Катусенко В. Тома Аквінський і його філософія / Тома Аквінський. Коментарі до Арістотелевої «Політики». Київ: Основи, 2003. С. 5-25.

4. Михайлов А. В. Обратный перевод. Москва: Языки русской культуры, 2000. 853 с.

5. Михед П. Слово художнє, слово сакральне. Ніжин: Аспект-Поліграф, 2007. 180 с.

6. Образцов С. В. Эстафета искусств. Изд. 3-е. Москва: Искусство, 1987. 240 с.

7. Попова И. Л. Историческая поэтика в теоретическом освещении. Москва: Институт мировой литературы РАН, 2015. 264 с.

8. Чижевський Д. Історія української літератури від початків до доби реалізму. Літературна редакція Ю. Шереха-Шевельова. Нью-Йорк: Українська Вільна Академія Наук у США, 1956. 512 с.

9. Шевчук В. Вершинний твір українського бароко. Літературознавче дослідження «Енеїди» I. Котляревського. Київ: Веселка, 2008. 38 с.

10. Шпет Г. Г. История как предмет логики // Историко-философский ежегодник 88. Москва: Наука, 1988. С. 290-320.

11. Юдкін-Ріпун І. Формування визначників української культури. Київ, 2008. (Інститут культурології Академії мистецтв України). 184 с.

\section{References}

1. Averincev S. S. «Morfologiya kul'tury» Osval'da SHpenglera // Novye idei v filosofii. 1991. M.: Nauka, 1991. S. 183-203. 
2. Bilec'kii A. O. «Il'ionyanka» - pershii povnii ukraïns'kii pereklad Gomerovoï «lliadi» / Rudans'kii S. Tvori v 3 t. T. 3. Kï̈v: Naukova dumka, 1973. S. 405-418.

3. Katusenko V. Toma Akvins'kii i iogo filosofiya / Toma Akvins'kii. Komentari do Aristotelevoï «Politiki». Kiïv: Osnovi, 2003. S. 5-25.

4. Mihailov A. V. Obratnyi perevod. Moskva: YAzyki russkoi kul'tury, 2000. $853 \mathrm{s.}$

5. Mihed P. Slovo hudojne, slovo sakral'ne. Nijin: Aspekt-Poligraf, 2007. $180 \mathrm{~s}$.

6. Obrazcov S. V. Estafeta iskusstv. Izd. 3-e. Moskva: Iskusstvo, 1987. $240 \mathrm{~s}$.

7. Popova I. L. Istoricheskaya poetika v teoreticheskom osveschenii. Moskva: Institut mirovoi literatury RAN, 2015. $264 \mathrm{~s}$.

8. CHijevs'kii D. Istoriya ukraïns'koï literaturi vid pochatkiv do dobi realizmu. Literaturna redakciya YU. SHereha-SHevel'ova. N'yu-Iork: Ukraïns'ka Vil'na Akademiya Nauk u SSHA, 1956. 512 s.

9. SHevchuk V. Vershinnii tvir ukraïns'kogo baroko. Literaturoznavche doslidjennya «Eneïdi» I. Kotlyarevs'kogo. Kï̈v: Veselka, 2008. $38 \mathrm{~s}$.

10. SHpet G. G. Istoriya kak predmet logiki // Istoriko-filosofskii ejegodgnik 88. Moskva: Nauka, 1988. S. 290-320.

11. Yudkin-Ripun I. Formuvannya viznachnikiv ukraïns'koï kul'turi. Kiïv, 2008. (Institut kul'turologiï Akademiï mistectv Ukraïni). $184 \mathrm{~s}$.

\section{Юдкин-Рипун И.}

\section{“Обратный перевод» как феноменологическая концепция развития культуры}

Широкое истолкование категории рефлексии в феноменологии обеспечивает возможности использования ее для освещения исторического бытия традиций. В частности, на основе рефлексии создаются обратные связи (рекурсия) между различными историческими фазами развития традиций, определяя его замкнутые циклы. Особую форму таких связей составляет феномен обратного перевода, в котором виртуальный оригинал предстает как внешний возбудитель внутренних преобразований традиции. Модель обратного перевода позволяет освещать такие вопросы украинского культурогенеза, как перманентность барочной традиции, своеобразие бидермейера и неоклассицизма.

Ключевые слова: рефлексия, рекурсия, циклизация, интерпретация, метафора бумеранга, эйдетика.

Yudkin-Ripun I.

"Reversed Translation" as the phenomenological concept of cultural development

The widened interpretation of the category of reflection within the phenomenology enables its applicability to elucidate the historical life of traditions. In particular it is the feedback (recursion) between different phases of a tradition's development that is built up on the basis of reflection determining thus the developmental closed cycles. As a special form of recursion the phenomenon of the4 so called reversed translation is to be considered where the primary imaginary original serves as the outer stimulus for the inner transformations of a tradition. The model of the reversed translation gives opportunities for the elucidation of such topics of Ukrainian cultural genesis as those of the permanence of baroque tradition, the particulars of Biedermeyer and neo-classics.

Keywords: reflection, recursion, cycles' formation, interpretation, the metaphor of boomerang, eidetic principles. 